\title{
Analogiese taal by Bultmann in die lig van die
}

\section{kennissosiologie ${ }^{1}$}

Gert Malan

\author{
Navorser: Departement Nuwe-Testamentiese Wetenskap
}

Universiteit van Pretoria

\begin{abstract}
A reflection on Bultmann's use of analogical language in the light of the sociology of knowledge

Bultmann's approach to analogical language, or as he put it, mythological language, was to demythologise it. Reaction to his demythologising program was largely negative, as it seemed radical to many. This study shows that Bultmann's approach to analogical language does not differ much from the way the concept "analogical language" is used within the sociology of knowledge. It seems that disciplines which had previously been practised in isolation from each other, developed their own terminology. The result is that essentially the same issues were referred to by different names, and that the same terms could be used to denote different issues. In this article the question whether analogical/mythologicalsymbolicalmetaphorical language is treated in much the same way by the two different approaches is answered positively.
\end{abstract}

\section{PROBLEEMSTELLING}

Een van die sentrale probleme vir die verstaan van die Nuwe-Testamentiese verkondiging is dat dit in mitologiese taal en te midde van ' $n$ mitologiese wêreldbeeld geformuleer is. Hierdie formulering is vir die twintigste-eeuse mens, met 'n moderne en wetenskaplike wêreldbeeld, moeilik verstaanbaar. Huidige benaderings in die eksegese worstel steeds met hierdie problematiek. Bultmann se ontmitologiseringsprogram was 'n grondige

1 Hierdie artikel is 'n verwerking van die resultate van die DD-proefskrif, "'n Herwaardering van Rudolf Bultmann se ontmitologiseringsprogram in die lig van die kennissosiologie: Die dag van die Here in 2 Petrus as voorbeeld." Hierdie proefskrif is ingedien en aanvaar as deel van die vereistes vir die DD-graad (1998), Departement Nuwe-Testamentiese Wetenskap, Fakulteit Teologie (Afdeling A), Universiteit van Pretoria, onder leiding van prof dr A G van Aarde. 
poging om die Nuwe-Testamentiese verkondiging vir die moderne mens eksistensieel verstaanbaar te maak. Die resultate van sy navorsing is egter deur vele as kettery afgemaak en word tot vandag toe nog deur baie teoloë met agterdog bejeën. Die vraag is egter of sy resultate werklik so radikaal en ketters was. As daar vandag 'n benadering sou wees wat op soortgelyke wyse as Bultmann na Nuwe-Testamentiese tekste kyk, en wat aanvaarding binne die Nuwe-Testamentiese wetenskap geniet, dan behoort Bultmann se benadering en die magdom van sy resultate soortgelyke aandag en erkenning te kry. Die winspunt sou wees dat sodanige benadering baat sou kon vind by die nalatenskap van Bultmann. Hierdie opstel poog om ooreenkomste aan te toon tussen Buitmann en die kennissosiologie se benadering tot analogiese taal, ten einde Bultmann se resultate op hierdie terrein vir die kennissosiologie te ontsluit.

\section{ANALOGIESE OF METAFORIESE TAAL}

Die term analogie het sedert die Kantiaanse epistemologiese revolusie van besondere belang geword. Kant het epogmakend geredeneer dat die metafisiese werklikheid nie as sodanig onderskeibaar en kenbaar is nie en dat die transendente slegs kenbaar is deur analogie of simbole (kyk Hopper 1987:54). Kant het oortuigend aangetoon dat die mens (as subjek) nie die werklikheid (as objek) as sodanig kan ken nie. Werklikheid word geken deur die wyse waarop die werklikheid sigself aan die mens voordoen. Analogiese taal word gebruik omdat ons min weet oor iets (in Kantiaanse terme die Ding an sich, of die Nouomenon) maar dit tog betekenisvol kan verduidelik aan die hand van iets anders waaroor ons meer weet (die Erscheinung of Phenomenon) (vgl Van Aarde 1991:55, n a v McFague 1983:15).

Sedert Kant is metafisiese kennis deur invloedryke teoloë soos Schleiermacher en Bultmann in analogiese taal geartikuleer (Allen 1985:217). In die tydperk voor Kant het die algemene idee bestaan dat die metafisiese werklikheid (die simboliese universum in kennissosiologiese terme), net soos die immanente werklikheid, onderskeibaar en kenbaar is. Die term analogiese taal kom nie algemeen in die literatuur voor nie. In die filosofiese sowel as literatuurteoretiese werke word die begrip metaforiese taal eerder gebruik. Waar daar wel na analogiese taal of analogie verwys word, geskied dit gewoonlik ook nie altyd met dieselfde betekenisinhoud nie. 
Daar is ' $n$ semantiese oorvleueling tussen die terme analogie en metafoor. Met behulp van 'n metafoor word een saak in terme van iets anders beskryf. So kan 'n mens voorgee dat iets gelyk is aan iets anders omdat ons nie weet hoe om oor iets te praat nie. Metaforiese gebruik van taal, wat te make het met die simboliese funksie van taal, kom voor wanneer ' $n$ mens voorgee dat daar 'n ooreenkoms bestaan tussen twee verskillende objekte, sake, gebeure en dies meer, en waar ons meen dat ons meer weet van die een as van die ander. So word die een waarvan ons meer weet, dan gebruik om iets meer te sê oor die een waarvan ons minder weet (Van Aarde 1991:5-6).

Kant se verduideliking van analogiese taal toon sterk, byna woordelikse ooreenkoms met wat onder metaforiese taal verstaan word. Metafoor beteken om iets in terme van iets anders te sien, "... pretending 'this' is 'that' because we do not know how to think about 'this', so we use 'that' as a way of saying something about it" (McFague 1983:15). Dit is vanuit die bogenoemde agtergrond en in hierdie terme dat analogiese taal en metaforiese taal in hierdie studie as uitruilbare terme beskou word.

Analogiese/metaforiese taal het ooglopend belangrike implikasies vir wetenskaplike teorievorming, en dit geld vir sowel die kennissosiologie as vir die teologie. Sonder analogieë/metafore kan teologie in die Kantiaanse paradigma nie beoefen word nie, want wat ons van God weet, weet ons deur middel van analogieë (Van Aarde 1991:5). Tot hierdie metaforiese gebruik van taal hoort die mite. Bultmann (1967a:23) dui aan dat die mite “... redet vom Unweltlichen weltlich, von den Göttern menschlich." Volgens hom verleen die mite aan die transendente werklikheid 'n immanente wêreldlike objektiwiteit. Die mite objektiveer die transendente (das Jenseitige) tot die immanente (das Diesseitigen) (Bultmann 1965:146).

\title{
3. BULTMANN SE BESKOUING OOR ANALOGIESE/ METAFO- RIESE TAAL
}

\begin{abstract}
Von Gottes Handeln reden, heißt zugleich von meiner Existenz reden. Da menschliches Leben ein Leben in Raum und Zeit ist, kann die Begegnung Gottes für die Menschen nur ein Ereignis jeweils hier und jetzt sein. Dieses Ereignis, von Gott hier und jetzt angeredet, gefragt, gerichtet, gesegnet zu werden, ist gemeint in der Rede vom Handeln Gottes. Vom Handeln Gottes
\end{abstract}


zu reden, ist also nicht bildliche, symbolische Redeweise, aber allerdings “analogische” Rede. Denn in solcher Rede stellen wir Gottes Handeln als menschlichen Handeln vor, und wir stellen uns die Gemeinschaft zwischen Gott und Mensch analog der Gemeinschaft zwischen Mensch und Mensch vor.

(Bultmann 1965:196) (Oorspronklike beklemtoning)

Bultmann verwys na Erich Frank se uiteensetting van die begrip analogie wat ten grondslag van sy eie aanwending daarvan lê (Bultmann 1965:196 nota 1). Uit Frank se definisie kom die Kantiaanse invloed sterk na vore: “... one may characterize analogy as similarity of relations in general, as a relation of relations. Thus the relation between two terms can be called an analogy" (Frank 1945:162). Frank (1945:179 nota 56) verwys ook na Kant se opmerking dat dit in die filosofiese sin van analogie oor die analogie tussen twee kwalitatiewe verhoudings gaan. Uit wat hierbo gesê is, lyk hierdie definisie van analogiese taal as versoenbaar met die begrip metaforiese taal te wees.

Dit word bevestig deur Frank se opmerking oor metaforiese taal: "Man in his discourse with God can only use his own words. If he speaks of God as Our Lord and Father, of his will, his providence, all such concepts are taken from human life; they are not to be understood literally, but rather as metaphors" (Frank 1945:97). Uit hierdie aanhaling, wat byna woordeliks ooreenkom met dit wat Bultmann hierbo oor die mens se spreke oor God sê, maar dit net analogiese taal genoem het, noem Frank metafore. Dit lyk inderdaad asof ons hier met uitruilbare terme te doen het.

Bultmann maak ' $n$ besliste onderskeid tussen analogiese taal en simboliese taal in sy opstel van 1952 oor die probleem met betrekking tot ontmitologisering. Die handelinge van God word nie as simbolies voorgestel nie, maar as handelinge in die gang van die natuur of geskiedenis. So 'n wonder van God is egter nie objektief waarneembaar nie, maar slegs deur die geloofsoog. Alleen so word die verborge dade van God in die natuurlike gebeure waargeneem (Bultmann 1965:196-197). Die dade van God word dus nie as simboliese handelinge geteken nie, maar as werklike historiese gebeure wat deur die mitologie besondere betekenis ontvang. So is die kruis van Christus geen mitiese (of simboliese) gebeurtenis nie, maar 'n historiese gebeurtenis wat gegrond is in die werklike 
kruisiging van Jesus van Nasaret. Die betekenis van die kruisiging kan egter nie sonder meer uit die gebeure self vasgestel word nie. "Die mythologische Rede will im Grunde nichts anderes als eben die Bedeutsamkeit des historischen Ereignisses zum Ausdrück bringen" (Bultmann 1967a:43). Hienuit kan afgelei word dat die analogie deur die mite daargestel word, en dat die mitologiese betekenistoekenning met die term analogiese taal aangedui sou kon word.

In sy Shaffer Lectures wat hy in 1951 in die V S A aangebied het, en wat in 1958 gepubliseer is onder die titel Jesus Christ and mythology brei Bultmann meer hieroor uit: "... to speak of God as acting does not necessarily mean to speak in symbols or images. Such speech must be able to convey its full and direct meaning" (Bultmann 1958:68).

Hierdie onderskeid tussen analogiese en simboliese taal is vir Bultmann baie belangrik. Wanneer ons oor God se optrede praat, bedoel ons daarmee dat ons byvoorbeeld deur God aangespreek, bevraagteken, geoordeel of geseën word. As ons só oor God praat, praat ons analogies en nie simbolies nie. Dit is 'n analogiese manier van praat, omdat ons oor God se optrede teenoor ons praat as analogies aan die optrede van mense teenoor mekaar. Hy verduidelik die verskil tussen simboliese en analogiese taal deur daarop te wys dat wanneer ons analogies oor God as ons Vader praat, praat ons nie oor 'n idee (d w s 'n simbool) van God nie, maar oor God self: "Thus, God's love and care et cetera, are not images and symbols; these conceptions mean real experiences of God as acting here and now" (Bultmann 1958:69).

Dit is belangrik om raak te sien dat Bultmann tog sê dat mitologiese taal as simbole en beelde gebruik kan word, maar dat wanneer mitologiese taal die taal van geloof dien, dit die mitologiese betekenis verloor en ontmitologisering vereis (Bultmann 1958: 67). Dit wil dus voorkom asof Bultmann onder analogiese taal ook mitologiese taal (waaronder simbole en beelde ingesluit kan word) in diens van die geloofstaal bedoel, en dan spesifiek mitologiese taal waarvan die volle en direkte betekenis (met ander woorde die analogie) deur ontmitologisering en gepaardgaande eksistensiale interpretasie geïdentifiseer kan word. Die afleiding wat ek hierbo gemaak het dat mitologiese taal ooreenstem met analogiese taal, blyk dus geregverdig te wees.

In hierdie verband lyk dit gepas om daarop te wys dat Wellek \& Warren (1977: 186) vanuit 'n literatuurteoretiese oogpunt daarop wys dat beeldspraak (image), meta- 
Die kennissosiologiese benadering tot die lees van die Nuwe-Testamentiese tekste is deel van die breë veld van die sosiaal-wetenskaplike studie van die Nuwe Testament. Dit beteken dat die kennissosiologie nie geïsoleerd staan nie, maar steeds beïnvloed word deur die breë veld van die sosiaal-wetenskaplike studieveld. Die resultate daarvan word byvoorbeeld vrugbaar aangewend in kultuur-antropologiese studies (vgl Douglas 1984:728). Die sosiaal-wetenskaplike benadering wat poog om Nuwe-Testamentiese tekste vanuit sosiale en kulturele kontekste te interpreteer, is aan die begin van die negentiger-jare beskryf as nog in ' $n$ infantiele fase (Van Staden 1991:iv). Een van die toonaangewende eksponente van hierdie benadering beskryf die groei tot volwassenheid van die sosiaalwetenskaplike benadering soos volg:

The process can be expected to be a slow, laborious one while the practitioners gradually develop new ways of thinking, speaking and looking, new research methods and objectives, new perspectives and frames of reference, new theories and conceptional models, new vocabularies, new means for collecting and organising data, new modes and standards of interpretation and new and more inclusive bodies of research.

(Elliott 1986:2)

Met al hierdie aanduidings van alles wat van nuut af aan moet ontwikkel, is dit nie verbasend dat Elliott die groei tot volwassenheid as 'n moeisame en tydsame proses beskryf nie. Die indruk word geskep dat die Nuwe Testament opnuut met 'n nuwe stel lense bekyk moet word, en dat dit wat deur hierdie nuwe lense van die sosiaal-wetenskaplike benadering gesien word, ook nuut sal wees (Elliott, in Van Staden 1991:iv).

Die kennissosiologiese benadering binne die sosiaal-wetenskaplike studie van die Nuwe Testament is een van die reeks nuwe lense om die Nuwe Testament mee te beskou (kyk o a Scroggs 1980:175). Die kennis-sosiologie moet as sodanig egter nie as 'n interretasiemodel gesien word nie. Berger \& Luckmann (1975:14), bekende eksponente van die kennissosiologie, stel dit dat “... our enterprise is one of sociological theory, not of the methodology of sociology." Die kennissosiologiese benadering is 'n filosofies-fenomenologiese hermeneutiese benadering tot die sosiale werklikheid (Van Staden 1991:67 
en vir wie die tekste geskryf was, binne te dring. Juis hier is die kennissosiologiese benadering van groot waarde. Dit gaan vir hom oor die stel van vrae wat sentraal was in die omstandighede tydens die ontstaan van 'n antieke teks en nie aan dié van ons eie era nie. Daarby moet die idee vermy word dat 'n woord of begrip 'n sekere tydlose betekenis verkry het. Saam met vrae oor die genre van die teks, moet ook gevra word na die bedoeling wat 'n outeur met juis daardie genre gehad het, asook die manier waarop die genre aangewend is. Daar moet ook gewaak word teen die uitspreek van waarde-oordele oor die teks omdat gedeeltes dalk die moderne uitlegger in verleentheid kan stel, soos byvoorbeeld die wondervertellings. Die proses van sosiale en kulturele verandering binne die Nuwe-Testamentiese periode moet ook in ag geneem word. Volgens Kee lewer die kennissosiologiese benadering ' $n$ belangrike bydrae tot ' $n$ duideliker verstaan van die teks.

Die vraag wat in hierdie studie aan die orde kom, is naamlik of die kennissosiologiese benadering as nuwe lens om Nuwe-Testamentiese tekste te lees, werklik so nuut is en of daar nie reeds vroeër deur 'n soortgelyke lens na die Nuwe Testament gekyk is nie. Daar word van die hipotese uitgegaan dat daar wel 'n duidelike ooreenkoms bestaan tussen die ontmitologiseringsprogram en gepaardgaande eksistensiale interpretasie van Rudolf Bultmann en die kennissosiologiese benadering. Die hipotesestelling dat hierdie onderskeie stelle lense nie so verskillend is as wat met die eerste oogopslag vermoed word nie, sal in hierdie studie beredeneer word aan die hand van die wyse waarop analogiese taal deur beide benader word.

Die effektiewe beredenering van die hipotese hou belangrike voordele in vir toekomstige navorsing vanuit die kennissosiologiese hoek. Die magdom hermeneutiese resultate wat Rudolf Bultmann ontgin het, kan moontlik dan vir die nuwe benadering ontsluit word. Sodoende kan 'n belangrike bydrae gelewer word om binne die kennissosiologie die groei van hierdie benadering tot volwassenheid aansienlik te bespoedig.

\section{DIE KENNISSOSIOLOGIESE VERSTAAN VAN}

\section{ANALOGIESE/METAFORIESE TAAL}

Sosiale interaksie is in wese ' $n$ vorm van kommunikasie. Kommunikasie in terme van taal is dan die proses waardeur een of meer persone (die bron) aan 'n ander persoon of 
foor, simbool en mite terme is wat semanties oorvleuel. Van Aarde (1991:55) praat van metaforisiteit as analogiese taal, en dit lyk asof die semantiese oorvleueling waarvan Wellek \& Warren praat, ook simbool en mite onder analogiese taal kan kategoriseer. Die aanvanklike keuse om die begrippe analogiese taal en metaforiese taal as uitruilbare terme te gebruik, skyn nie alleen 'n verantwoorde keuse te wees nie, maar ook om die interpretasie van mitologiese taal in te sluit.

\section{DIE KENNISSOSIOLOGIESE BENADERING}

Binne die sosiologiese wetenskap het die kennissosiologie ontwikkel as 'n soort neweproduk van die filosofiese werk van Max Scheler. Karl Mannheim was vir die klassieke formulering daarvan verantwoordelik. Alfred Schutz het die daaropvolgende verfyning aangebring en dit het weer 'n groot invloed uitgeoefen op die oortuigings van Berger (en Luckmann) as resente eksponente daarvan (kyk Kee 1989:10-11). Die kennissosiologie gaan van die basiese veronderstelling uit dat die werklikheid 'n sosiale konstruksie is. In hierdie benadering is werklikheid en kennis die sleutelwoorde. Werklikheid kan gedefinieer word as 'n sekere kwaliteit wat aan fenomene toegeken word wat onafhanklik van die menslike wil bestaan. Kennis kan beskryf word as die sekerheid dat die fenomene werklik bestaan en oor besondere kwaliteite beskik (Berger \& Luckmann 1975:13).

Die taak van die kennissosiologie kan beskryf word as die analise van die sosiale konstruksie van die werklikheid. Dit beteken dat die dissipline gefokus is op wat ook al as kennis in 'n bepaalde gemeenskap geld, ten spyte van die uiteindelike geldigheid of ongeldigheid daarvan. Die behoefte aan 'n kennissosiologie spreek vanself uit die waarneembare verskille tussen gemeenskappe oor wat as kennis aanvaar word. Kennis-sosiologie ondersoek egter nie net die empiriese verskeidenheid van kennis nie, maar ook die prosesse waardeur daardie korpus van kennis sosiaal as werklikheid daargestel word (Berger \& Luckmann 1975:15).

Die metode van die kennissosiologie is die fenomenologiese analise van die alledaagse werklikheid, dit wil sê 'n suiwer deskriptiewe metode en as sodanig empiries. Die wetenskaplikheid daarvan is egter nie geleẽ in die feit dat kousale of genetiese hipoteses daargestel word nie, en afleidings oor die ontologiese status van fenomene word ook nie gemaak nie (Berger \& Luckmann 1975:33-34). 
nota 15), en kan die teoretiese raamwerk vir die interpretasie van Nuwe-Testamentiese tekste bied (Petersen 1985:171 nota 2).

Wanneer dit by eksegese kom, kan die sosiaal-wetenskaplike benadering beskou word as 'n aanvullende komponent van die histories-kritiese metode met 'n drieledige studieveld: die sosiale aspekte wat deur die vorm en inhoud van tekste, teen die agtergrond van hulle onderskeie kontekste en kommunikasieprosesse na vore gebring word, die korrelasie tussen tekste se linguistiese, literêre, teologiese (ideologiese) en sosiale dimensies; en laastens, die manier waarop tekste funksioneer as refleksie van en respons op 'n spesifieke sosiale en kulturele konteks. Die sosiaal-wetenskaplike metode kan beskou word as 'n sub-dissipline van die eksegese wat onlosmaaklik deel vorm van ander eksegetiese prosedures, soos tekskritiek, literêre kritiek, narratiewe analise, tradisie-, vorm- en redaksiekritiek, retoriese en teologiese kritiek. "Social-scientific criticism complements these other modes of critical analysis, all of which are designed to analyze specific features of the biblical texts" (Elliott 1993:7).

Breedweg gesien lewer die sosiaal-wetenskaplike benadering tot tekste antwoorde op die vraag hoe antieke gemeenskappe georganiseer was en hoe dit gefunksioneer het. Hoewel die histories-kritiese metode bekend is vir detail analise in verband met individue, gebeure en sosiale instellings, was daar rondom hierdie aspek tog 'n leemte. Wat nodig was, was 'n manier om die verhouding te ondersoek tussen teks en sosiale konteks, idees en die gedrag van gemeenskappe, sosiale werklikhede en godsdienstige simbolisering daarvan asook geloofsisteme, kulturele sisteme en ideologieë, en uiteindelik ook die verhouding tussen hierdie sisteme en die natuurlike en sosiale, ekonomiese en politieke magstrukture (Elliott 1993:13). Een van die belangrikste bydraes van die kennissosiologiese benadering tot die lees van Nuwe-Testamentiese tekste is dat wêrelde as menslike konstruksies beskou word, hetsy konstruksies van gemeenskappe of vertellers. Dit beteken dat 'n teks se narratiewe wêreld as konstruksie, uit soortgelyke sosiale aspekte as die werklike wêreld saamgestel word, naamlik uit 'n simboliese en 'n sosiale universum. Die narratiewe wêreld van 'n teks kan derhalwe bestudeer word soos enige ander wêreld (Petersen 1985:ix).

Volgens Kee (1989:22-26) is dit vir die eksegeet van Nuwe-Testamentiese tekste juis noodsaaklik om analities die leefwêrelde van die onderskeie gemeenskappe waarin 
groep (die ontvanger) in gegewe omstandighede (die situasie) met 'n gesproke of geskrewe uiting (die kanaal) iets weergee oor 'n wêreldobjek (die boodskap) met die oog op 'n sekere uitkoms (die effek). Op dieselfde manier kan die boodskap in simboliese taal enkodeer word om so iets oor die alledaagse werklikheid te sê (Malina 1986:75-76). Mary Douglas (1972:60) meen selfs dat simbole die enigste manier van kommunikasie is. Vir haar is simbole die enigste manier om waardes mee uit te druk, en dien as die basiese meganismes van denke asook die enigste reguleerders van ervaring.

Hierdie enkodering in simboliese taal hou verband met die feit dat die werklikheid van die alledaagse lewe alleen moontlik is vanweë die objektiverings wat mense maak oor subjektiewe prosesse. Objekte wat die subjektiewe intensies van ander aandui, omring elke mens. Wat hierdie subjektiewe intensies is, is nie altyd ewe duidelik nie. Die probleem kan opgelos word deur die proses van objektivering. 'n Besonder belangrike voorbeeld hiervan is die mens se daarstelling van 'n tekensisteem. 'n Teken word van ander objektiverings onderskei deur die teken se eksplisiete intensie om as 'n indeks van subjektiewe betekenis te dien (Berger \& Luckmann 1975:49-50).

Taal is die belangrikste tekensisteem van die menslike gemeenskap. Die algemene objektiverings van die alledaagse lewe word primêr deur die taal as teken-sisteem in stand gehou. Taal ontstaan in die een tot een gespreksituasie, maar kan ook losgemaak word van daardie situasie. Taal het die vermoë om die hier en nou te transendeer. Hierdie transendensie het ruimtelike, temporele en sosiale dimensies. Die gevolg is dat taal die potensiaal het om 'n verskeidenheid objekte teenwoordig te maak in die hede wat eintlik in terme van ruimte, tyd en die sosiale aard daarvan afwesig is van die hier en nou. Deur taal is dit dus moontlik dat 'n totale wêreld op enige gegewe oomblik geaktualiseer kan word (Berger \& Luckmann 1975:51-54). Taal dra 'n verborge las van gedeelde veronderstellings, 'n kollektiewe en gedeelde stel interpretasies van die werklikheid wat die betrokke kultuur van 'n groep vorm. Die interpretasie van enige teks behels daarom tegelyk die interpretasie van die sosiale sisteem wat dit verteenwoordig (Malina 1986:2).

Die maksimum verwydering van die hier en nou binne die taalsisteem geskied deur simboliese taal wanneer taal in 'n gebied ingaan wat a priori nie toeganklik is vir alledaagse ervaring nie. Simboliese taal is moontlik omdat taal die vermoë het om die 
werklikheid van die alledaagse lewe te transendeer. Op hierdie manier konstrueer taal magtige simboliese voorstellings wat voorkom soos reusagtige teenwoordighede uit 'n ander wêreld en wat bo die alledaagse werklikhede troon. Taal het nie alleen die vermoë om simbole te konstrueer wat verwyder is van die alledaagse ervaring nie, maar kan ook hierdie simbole terugbring as objektiewe werklikhede in die alledaagse lewe. Op hierdie manier word simboliek en simboliese taal onomwonde deel van die alledaagse werklikheid. Histories is godsdiens, filosofie, kuns en natuurwetenskap belangrike simboliese sisteme, wat selfs ten spyte van die soms maksimale verwydering van die werklikheid tog vir die alledaagse lewe van groot belang is (Berger \& Luckmann 1975:54-55).

Alhoewel die terme analogiese taal en metaforiese taal nie juis in die kennissosiologie aangewend word nie, figureer die term simboliese taal sterk, veral waar daar oor die transenderende moontlikhede van taal gepraat word. Die vraag is of dit wat onder simboliese taal verstaan word, te versoen is met die begrip analogiese/metaforiese taal soos dit hierbo beskryf is.

Simboliese taal soos deur die kennissosiologie gesien, kan ooglopend gemaklik met die Kantiaanse definisie van analogiese taal versoen word, sowel as met die begrip metaforiese taal. Die vraag is egter of Bultmann se besliste onderskeid tussen analogiese en simboliese taal, die kennissosiologiese siening van simboliese taal uit die breë definiëring van analogiese taal uitsluit. Anders gestel: is dit wat Bultmann met die term simboliese taal bedoel, dieselfde as die kennissosiologiese verstaan daarvan?

Vir Bultmann is dit belangrik dat die spreke oor God nie net simbolies of beeldend sal wees nie, maar 'n direkte afleesbare betekenis sal hê, met ander woorde 'n betekenis wat dadelik verstaanbaar is in terme van die alledaagse werklikheid. Aan hierdie vereiste voldoen die kennissosiologiese definisie as gevolg van die beklemtoning van die moontlikheid van taal om die simbool weer deel van die alledaagse werklikheid te laat wees. Hierdie potensiaal van taal sou ook die interpretasie van mites wat in diens van geloofstaal is, moontlik maak, sodat mites se volle en direkte betekenis blootgelê kan word.

Die ander beswaar wat Bultmann teen simboliese taal met betrekking tot die spreke oor God het, is dat die dade van God sodoende slegs as simbole voorgestel word en nie as werklike historiese gebeure nie. Hy lê sterk klem daarop dat die dade van God 
deur analogiese taal as werklike historiese gebeure geteken word wat deur die mite besondere betekenis ontvang. Dit lyk egter of die begrip simboliese taal, soos deur die kennissosiologie aangewend, tog die ruimte daarvoor sou laat dat gebeure binne die alledaagse werklikheid danksy die transendente moontlikheid van taal, vanuit die simboliese konstruksie besondere betekenis sou kon ontvang.

Dit wil voorkom asof die kennissosiologiese omskrywing van die begrip simboliese taal veel omvattender is as Bultmann se aanwending daarvan, en eerder met sy gebruik van die begrip analogiese taal te versoen is. Die twee sake wat volgens die hipotese met mekaar in verband gebring word, naamlik die benadering tot analogiese/metaforiese/mitologiese/simboliese taal deur Bultmann en die kennissosiologie, word dus legitiem met mekaar vergelyk. Appels word wel met appels vergelyk.

Uit die hele worsteling om te probeer vasstel wat met die begrip analogiese taal bedoel word, kom die waarheid van Elliott (1986:2) se uitspraak duidelik na vore, naam* lik dat waar daar 'n samesmelting van vroeër geïsoleerde dissiplines was, elk met 'n eie terminologie, daar heelwat verwarring verwag kan word. Hopelik het daar uit die verwarring genoegsame orde na vore getree sodat die kennissosiologiese benadering tot analogiese taal met Bultmann s'n vergelyk kan word.

\section{BULTMANN SE BENADERING TOT ANALOGIESE TAAL}

Die vraag na Bultmann se benadering tot analogiese taal is, om Bultmann se eie terme te gebruik, die vraag na sy benadering tot mitologiese taal. Om te bevestig dat die vraagstelling legitiem is, naamlik dat analogiese, metaforiese, mitologiese en simboliese taal, soos dit in die onderskeie dissiplines vorendag kom, wel met mekaar in verband gebring kan word, word gewys op Bultmann se siening dat dit nie soseer die begrip mite is wat belangrik is nie. Hy het vrede daarmee as iemand iets anders onder die begrip wil verstaan, hoewel hyself vir die begrip kies soos wat dit in die Godsdienswetenskap gebruik word (Bultmann 1965:180). Aksentverskuiwings wat die verskillende dissiplines aan hulle onderskeie begrippe toeken, kan dus geredelik geakkommodeer word.

\subsection{Die onderskeid tussen wetenskaplike en mitologiese denke}

Bultmann definieer mite en mitiese denke soos volg: 
Mythos ist der Bericht von einem Geschehen oder Ereignis, in dem übernatürliche, übermenschliche Kräfte oder Personen wirksam sind (daher oft einfach als Göttergeschichte definiert). Mythisches Denken ist der Gegenbegriff zum Wissenschaftlichen Denken. Das mythische Denken führt bestimmte Phänomene und Ereignisse auf übernatürliche, auf "göttliche" Mächte zurück.

(Bultmann 1965:180)

Bultmann wys daarop dat wetenskaplike denke nie die invloed van bonatuurlike magte erken nie, aangesien daar in die natuurwetenskappe geredeneer word vanuit 'n geslote samehang tussen oorsaak en gevolg, 'n geslote wêreldbeeld. Gevolglik is daar 'n eenheid in die wêreld, asook 'n eenheid in die wetenskaplike denke. Daarteenoor is daar 'n onsamehangendheid binne die mitologiese vertellings, en word die wêreld en wêreldgebeure beskou as oop, naamlik vir die invloed van bonatuurlike magte (Bultmann 1965: 181).

\subsection{Mitologiese wêreldbeeld as alles-oorkoepelende verwysingsraamwerk}

Met Bultmann se definisie van mite en mitologiese denke in gedagte, kan voortgegaan word om sy benadering tot analogiese taal te beskryf. Die wesenlike aspek tot die verstaan van sy benadering tot analogiese taal is sy antwoord op die vraag na die bedoeling van mitologiese spreke. Hieraan is reeds hierbo aandag gegee. Met betrekking tot die bespreking van Bultmann se benadering tot analogiese taal is dit nodig om sy verstaan van die intensie van mitologiese spreke kortliks weer te gee. Om saam te vat: Hy beantwoord die vraag na die intensie van die mite soos volg: Die mite praat van die invloed van bonatuurlike magte op die lewens van mense. Aan die een kant word hierdie bonatuurlike magte gevrees, en aan die ander kant word gepoog om hulle guns te verkry. Mitologiese spreke bring die werklikheid tot uitdrukking dat mense nie beheer oor hulle lewens het nie, en worstel met talle onbeantwoorde vrae en raaisels. Die intensie van die mite is om “... ein bestimmtes Verständnis der menschliche Existenz ..." tot uitdrukking te bring (Bultmann 1965:183) (oorspronklike beklemtoning). Anders gestel: mitologisering is die gevolg van ' $n$ besondere verstaan van menslike eksistensie. 
Dat dit ' $n$ alles oorkoepelende verwysingsraam tot gevolg het, is duidelik te sien in die drieverdieping mitologiese wêreldbeeld van die Nuwe Testament. Dit kom neer op 'n gelaagde siening van die wêreld, wat met 'n toebroodjie vergelyk kan word. Die sfeer van menslike bestaan word deur die bo- en onderwêreld omvat, soos die vulsel tussen die twee snye brood van 'n toebroodjie. Volgens hierdie siening is mense se bestaan onomwonde vasgevang tussen goedgesinde en vyandige bonatuurlike magte wat hulle lewens beïnvloed. Tegelyk bied dit singewing aan hulle bestaan wat sonder 'n aanvaarbare alternatief, so sinloos sou wees as die vulsel sonder die twee snye brood. So bied die mitologie 'n alles oorkoepelende sisteem of raamwerk waarbinne mense bestaan, en hulle bestaan probeer verstaan.

\subsection{Die objektiverende aard van mitologiese taal}

Mites praat oor gode en hulle optrede soos wat daar oor mense en hulle optrede gepraat word. Die verskil is dat die gode bomenslike mag het en dat hulle optrede onvoorspelbaar is en wel in die natuurlike gang van sake kan ingryp. Kortom gestel: die mite objektiveer die transendente tot immanente, en sodoende tot die beheerbare (Bultmann 1965: 183-184).

\subsection{Ontmitologisering en eksistensiale interpretasie}

Die Entmythologisierung will die eigentliche Intention des Mythos zur Geltung bringen, nämlich die Intention, von der Existenz des Menschen in ihrer Begründung und Begrenzung durch eine jenseitige, unweltliche Macht $\mathrm{zu}$ reden, eine Macht die dem objektivierenden Denken nicht sichtbar wird.

(Bultmann 1965:184)

Die eintlike doel van die mite is nie om 'n objektiewe wêreldbeeld voor te hou nie, maar om uitdrukking te gee van hoe mense hulleself in die wêreld verstaan. Om hierdie rede behoort mites nie kosmologies nie, maar eksistensiaal interpreteer te word (Bultmann 1967:22). Vir Bultmann is dit die positiewe sy van ontmitologisering. Die negatiewe sy 
daarvan is kritiek op die wêreldbeeld van die mite, omdat die wêreldbeeld die eintlike intensie van die mite verberg (Bultmann 1965:184).

Ontmitologisering as hermeneutiese metode vra na die regte verstaansraamwerk waarvan die verstaansbegrippe voldoende sal wees om die betekenis van die mitologies verwoorde Nuwe-Testamentiese verkondiging genoegsaam tot uitdrukking te bring. "Sie verwies damit auf eine Wissenschaft, deren Geschäft die methodische Ausbildung des mit der Existenz selbst gegebenen Existenzverständnisses ist, mit andern Worten auf die Existenz-Philosophie" (Bultmann 1965a:191).

Uit die staanspoor het Bultmann se keuse geval op Martin Heidegger se eksistensiale analise van Dasein, omdat dit vir hom die regte verstaansraamwerk bied. Hy sien dit as 'n profane filosofiese uitdrukking van die mitologies verwoorde Nuwe-Testamentiese beskouing van menslike Dasein (Bultmann 1967a:33). Hoe sien hierdie filosofie die mens? Dit sien mense as histories-eksisterend in die besorgdheid oor hulleself op grond van die angs waarmee hulle vervul is. Dit sien hulle as mense wat hulle telkens bevind in die oomblik van beslissing tussen die verlede en die toekoms. Hulle word gekonfronteer met die vraag of hulle hulleself sal verloor aan die voorhande wêreld en van ' $n$ mens (das Man) en uneigentlich (nie-outentiek) sal eksisteer, en of hulle eigentlich (outentiek) sal eksisteer in die prysgawe van alle sekerhede en in die onvoorwaardelike vry wees vir die toekoms. Hy vra: "Ist nicht so auch im Neuen Testament der Mensch verstanden?" (Bultmann 1967a:33).

Bultmann is bewus daarvan dat hierdie benadering beteken dat die eksegetiese arbeid afhanklik gemaak word van die filosofiese, maar hy is oortuig daarvan dat dit 'n illusie is om te dink dat eksegese enigsins sonder 'n profane stel begrippe uitgevoer kan word. Elke eksegeet is volgens hom in ieder geval afhanklik van een of ander vorm van filosofie. Dit hoef nie 'n probleem te wees nie, solank dit net nie onkrities en ongereflekteerd gebeur nie. Die deurslaggewende is uiteindelik om by die regte filosofie uit te kom (Bultmann 1965a:192).

Die eksistensiale interpretasie word met betrekking tot die Nuwe-Testamentiese tekste as hermeneutiese benadering gebruik om daardie bepaalde siening van menslike eksistensie bloot te lê, sodat moderne mense wat nie meer mitologies dink nie, steeds 
hierdie soort eksistensie as 'n moontlikheid vir hulle selfverstaan in die hede kan benut (Bultmann 1967a:17).

\section{KENNISSOSIOLOGIESE BENADERING TOT ANALOGIESE TAAL}

Om die kennissosiologiese benadering tot analogiese taal vas te stel, is 'n moeilike proses, aangesien, soos reeds daarop gewys is, die kennissosiologie nie 'n model vir die interpretasie van tekste wil wees nie (Van Staden 1988:341). Hierbo is reeds gewys op die transendente moontlikhede van taal en dat die soort taal waardeur die werklikheid getransendeer word, in die kennissosiologie as simboliese taal bekend staan. Daar is ook gewys daarop dat simboliese taal as wisselterm vir analogiese taal kan dien. Die kennissosiologiese verstaan van die begrip mite het egter nog nie na vore gekom nie. Mitologie word gedefinieer as: “... a concept of reality that posits the ongoing penetration of the world of everyday experience by sacred forces" (Berger \& Luckmann 1975:128). As hierdie definisie saamgelees word met die definisie van simboliese taal, is dit duidelik dat die taal van die mite in kennissosiologiese terme as simboliese taal beskryf kan word.

Vervolgens gaan dieselfde terreine bekyk word as by Bultmann se benadering tot analogiese taal, om later 'n vergelyking tussen die twee te maak.

\subsection{Die onderskeid tussen wetenskaplike en mitologiese denke}

In teenstelling met mitologie soos hierbo omskryf, ontneem die wetenskap as sekulariseringsproses juis die alledaagse wêreld van die sakrale (Berger \& Luckmann 1975:130). Dit is derhalwe interessant dat die definisie van simboliese taal, soos wat dit in die kennissosiologie funksioneer, ook die taal van die wetenskap insluit. Op die vlak van simboliese taal, wat dan beide die mite en die wetenskap se gebruik daarvan insluit, word die maksimum verwydering van die alledaagse werklikheid bereik. "Language now constructs immense edifices of symbolic representations that appear to tower over the reality of everyday life like gigantic presences from another world" (Berger \& Luckmann 1975: 55).

Hierdie konstruksie staan in die kennissosiologie as die simboliese universum bekend. Die mite en die wetenskap vorm die twee uiterste pole in die proses om die 
simboliese universum te legitimeer. Mitologiese denke aanvaar ' $n$ kontinü̈teit tussen die menslike wêreld en die wêreld van die gode. Dit lê met ander woorde op 'n meer naïewe vlak van die simboliese universum. Dit is 'n vlak waar daar die minste behoefte aan 'n teoretiese instandhouding van die universum nodig is, behalwe as om bloot die universum as 'n objektiewe werklikheid daar te stel.

Wetenskaplike denke vorm die ekstreme ontwikkeling in die masjinerie om die simboliese universum in stand te hou en is ook die mees gesofistikeerde. Alle sakrale legitimering word uit die alledaagse lewe in so 'n mate verwyder dat oningeligtes nie meer weet hoe hulle universum wel in stand gehou word nie. Hulle weet nog net wie die spesialiste in die instandhoudingsproses is (Berger \& Luckmann 1975:130).

\subsection{Simboliese universum as alles oorkoepelende en objektiverende verwysings- raamwerk}

Simboliese universums kan beskryf word as “... bodies of theoretical tradition that integrate different provinces of meaning and encompass the institutional order in a symbolic totality ..." (Berger \& Luckmann 1975:113). Die begrip simboliese universum is al beskryf as "... probably the most important contribution of the sociology of knowledge, as far as theology is concerned" (Van Staden 1988:344). Ek het reeds daarop gewys dat Petersen die kennissosiologiese begrippe inspan vir die interpretasie van Nuwe-Testamentiese tekste. Die begrip simboliese universum is een daarvan, en hy wys daarop dat wêrelde as menslike konstruksies, ook narratiewe wêrelde van tekste, saamgestel is uit dieselfde sosiale aspekte, naamlik simboliese vorme en sosiale instellings, wat onlosmaaklik aan mekaar verbonde is (Petersen 1985:ix).

Die verbondenheid van die sosiale universum (die sfeer van die daaglikse ontmoetings van aangesig tot aangesig) en die simboliese universum bestaan daaruit dat die oorsprong van die simboliese universum enersyds in die sosiale universum geleë is, en andersyds dat die simboliese universum as hoogste vlak van legitimering vir die sosiale universum dien (Petersen 1985:27).

Die sosiale universum as oorsprong van die simboliese universum kan soos volg verduidelik word: Die sosiale orde is 'n produk van menslike aktiwiteit wat aan die een kant die gevolg is van mense se voortgaande eksternalisering van hulleself, maar aan die 
ander kant ' $n$ werklikheid is wat die individue voorafgaan en wat hulle konfronteer as 'n werklikheid buite hulleself. Deur die proses van objektivering word die wêreld wat deur die mens geskep is, getransformeer: "The humanly produced world becomes something 'out there'. It consists of objects, both material and non-material, that are capable of resisting the desires of their producer .... It stands outside the subjectivity of the individual as, indeed, a world" (Berger 1973:18-19).

Hierdie wereld, wat gegrond is in die sosiale werklikheid as menslike produk, is die wêreld soos wat individue dit beleef, en staan as hulle sosiale universum bekend (Petersen 1985:29). Die implikasie is derhalwe dat die simboliese universum 'n menslike produk is, en as sodanig iets oor die mens self wat deur die proses van objektivering versluier word, te kenne kan gee.

Die ander verband tussen die sosiale en die simboliese universum is dat die simboliese universum as hoogste vlak van legitimering vir die sosiale universum dien: "Legitimation 'explains' the institutional order by ascribing cognitive validity to its objectivated meanings. Legitimation justifies the institutional order by giving normative dignity to its practical imperatives" (Berger \& Luckmann 1975:111).

Alle sektore van die institusionele orde word sodoende geïntegreer in 'n alles oorkoepelende verwysingsraamwerk wat 'n universum in die letterlike sin van die woord vorm, omdat alle menslike ervaring daarbinne plaasvind (Berger \& Luckmann 1975:114).

\subsection{Die fenomenologiese beskrywing}

Hierbo is die afleiding reeds gemaak dat die simboliese universum uit die aard van die oorsprong daarvan vanuit die sosiale universum, 'n menslike produk is en derhalwe iets oor die mens te kenne kan gee. In die woorde van Berger en Luckmann (1975:121-122):

The origins of a symbolic universe have their roots in the constitution of man .... As man externalizes himself, he constructs the world into which he externalizes himself. In the process of externalization, he projects his own meanings into reality. Symbolic universes, which proclaim that all reality is humanly meaningful and call upon the entire cosmos to signify the validity of human existence, constitute the furthest reaches of this projection. 
Met ander woorde, die simboliese universum kan beskryf word as die uiterste projeksie van die betekenis wat mense aan die werklikheid in hulle proses van eksternalisering toeken.

Die vraag na watter spesifieke betekenis daar oor die werklikheid in die simboliese universum geprojekteer is, is myns insiens tegelyk die vraag na mense se denke oor of verstaan van hulle eie betekenis binne die werklikheid. Dit stem ooreen met wat Van Staden (1988:341) as die sentrale probleem van die kennissosiologie aandui, naamlik die probleem van die "... existential determination (Seinsgebundenheit) of thought as such."

Om die alledaagse werklikheid te probeer verstaan maak die kennissosiologie gebruik van die fenomenologiese metode wat 'n suiwer deskriptiewe metode is (Berger \& Luckmann 1975:34).

\section{VOORLOPIGE GEVOLGTREKKING}

Die vraag wat aanvanklik gestel is, naamlik of die kennissosiologiese benadering as nuwe lens om Nuwe-Testamentiese tekste mee te lees, werklik so nuut is en of daar nie vroeër reeds deur 'n soortgelyke lens na die Nuwe Testament gekyk is nie, kan nou beantwoord word. Die vergelyking tussen Bultmann se benadering tot analogiese taal en dié van die kennissoiologie kan nou gefinaliseer word:

\subsection{Die onderskeid tussen mitologiese en wetenskaplike denke}

Dit blyk duidelik uit die uiteensetting hierbo dat 'n soortgelyke onderskeid tussen wetenskaplike en mitologiese denke deur beide benaderings gemaak word. Die definisies stem baie ooreen met mekaar. Die aanduiding vanuit die kennissosiologie dat beide die mitiese en die wetenskaplike denke bydra tot die vorming van simboliese universums vanweë die transendente moontlikheid van taal, vind 'n weerklank in Bultmann (1965a: 184) se onderskeid tussen die mitologiese en wetenskaplike wêreldbeeld. Die belangrikheid van hierdie onderskeid tussen mitologiese en wetenskaplike denke bestaan daaruit dat beide benaderings dit aanwend "... in a manner very suitable for interpreting, on an existential level ..." (Van Aarde 1991:56). 


\section{2 'n Alles oorkoepelende en objektiverende verwysingsraamwerk}

Uit Bultmann se omskrywing van die mitologiese wêreldbeeld van die Nuwe Testament, naamlik dat dit die totale universum omvat waarbinne menslike ervaring afspeel, is die ooreenstemming met die begrip simboliese universum ooglopend. Van belang is ook die ooreenstemming tussen die twee benaderings met betrekking tot die siening van die simboliese universum as menslike produk. Wat Bultmann Existenzverständnis noem, kan tot 'n groot mate versoen word met dit wat die kennissosiologie beskryf as ' $n$ projeksie van betekenis wat die mens aan die werklikheid toeken.

Bultmann merk op dat die mite oor God se handeling praat asof dit objektief waarneembaar is, en sodoende die transendente tot die immanente objektiveer. Die kennissosiologie sien weer die simboliese universum as die gevolg van die objektivering binne die sosiale universum wat die mens as objektiewe werklikheid konfronteer. By albei benaderings word die wisselwerking tussen mense en hulle simboliese universum/ mitologiese wêreldbeeld aangedui, sowel as die objektiverende aard van daardie universum.

\subsection{Interpretasie}

Die verskil tussen die twee benaderings kom hier sterk na vore, naamlik dat Bultmann eksistensiaal wil interpreteer, terwyl die kennissosiologie wil verstaan deur fenomenologies te analiseer en te beskryf. Hoewel die kennissosiologie nie 'n model vir interpretasie is nie, kan dit wel baie nuttig aangewend word met die oog op eksistensiale interpretasie (Van Aarde 1991: 56).

Hoewel die kennissosiologie as sodanig dus nie belangstel om tot die betekenis van byvoorbeeld ' $n$ simboliese universum deur te dring nie, maar dit te analiseer en te beskryf, kan dit 'n belangrike verwysingsraamwerk word vir die studie van die Nuwe-Testamentiese tekste (vgl Van Staden 1988:341).

\section{GEVOLGTREKKING}

Die hipotese dat daar wel 'n duidelike ooreenkoms bestaan tussen die kennissosiologiese benadering en Bultmann se ontmitologiseringsprogram, is beredeneer. Die twee benaderings kan inderdaad as twee lense van dieselfde bril beskou word waarmee daar na die 
tekste van die Nuwe Testament gekyk kan word. Dit hou verder in dat die hermeneutiese resultate van Bultmann vir die kennissosiologie ontsluit word. Hopelik sal Bultmann se benadering ook met minder agterdog bejeën word.

\section{Literatuurverwysings}

Allen, D 1985. Philosophy for understanding theology. Atlanta: John Knox.

Berger, P L 1973. The social reality of religion. Harmondsworth: Penguin.

Berger, P L \& Luckmann, T 1975. The social construction of reality: A treatise in the sosiology of knowledge. Harmondsworth: Penguin.

Bultmann, R K 1958. Jesus Christ and mythology. New York: Charles Scribner's Press.

- 1965. Zum Problem der Entmythologisierung, in Bartsch, H-W (Hrsg), Kerygma und Mythos, II: Diskussionen und Stimmen zum Problem der Entmythologisierung, 179-195. Hamburg-Bergstedt: Herbert Reich Evangelischer Verlag. (ThF2.)

- 1967. Neues Testament und Mythologie: Das Problem der Entmythologisierung der neutestamentlichen Verkündigung, in Bartsch, H-W (Hrsg), Kerygma und Mythos, I: Ein theologisches Gespräch, 15-48. Hamburg-Bergstedt: Herbert Reich Evangelischer Verlag. (ThF1.)

Douglas, M T \& Douglas, M T 1972. Deciphering a meal. Daed 101,61-81.

- 1984. Purity and danger: An analysis of the concepts of pollution and taboo. London: Ark.

Elliott J H 1986. Social-scientific criticism of the New Testament: More on methods and models. Semeia 35, 1-33.

- 1993. What is social-scientific criticism? Mineapolis: Fortress. (Guides to Biblical Scholarship: New Testament Series.)

Frank, E 1945. Philosophical understanding and religious truth. London: Oxford University Press.

Hopper, J 1987. Modern Theology, I: Cultural revolutions and new worlds. Philadelphia: Fortress.

Kee, H C 1989. Knowing the truth: A sociological approach to the New Testament interpretation. Minneapolis: Fortress. 
Malina, B J 1986. Christian origins and cultural anthropology: Practical models for biblical interpretation. Atlanta: John Knox.

McFague, S 1983. Metaphorical theology: Models of God in religious language. London: SCM.

Pelser, G M M 1987. Die ontmitologiseringsprogram van Rudolf Bultmann. HTS 43, 162-191.

Petersen, N R 1985. Rediscovering Paul: Philemon and the sociology of Paul's narrative world. Philadelphia: Fortess.

Scroggs, R 1980. The sociological interpretation of the New Testament: The present state of research. NTS 26, 164-179.

Van Aarde, A G 1991. "The most high God does not live in houses built by men": The relativity of the metaphor "Temple" in Luke-Acts. Neotestamentica 25/1, 51-64.

Van Staden, P 1988. A sosiological reading of Luke 12:35-48. Neotestamentica 22, 337353.

- 1990. Compassion - the essence of life: A social-scientific study of the religious symbolic universe reflected in the ideology/theology of Luke. Pretoria: University of Pretoria. (HTS Suppl 4.)

Wellek, R \& A Warren 1977. Theory of literature. New revised edition. New York: Harcourt Brace Janovich. 